\title{
Entrepreneurial Organizational Culture During a Pandemic in a Labour-Intensive Industry: The Mediating Role of Fear of COVID-19, Psychological Distress, and Job Satisfaction in Turnover Intention
}

DOI: 10.7595/management.fon.2021.0038

Abstract:

Motivation and idea: Entrepreneurial culture has been considered to have a significant positive relation with the organizational growth and self-efficacy. However, the success of entrepreneurial culture has been challenged by the COVID19 pandemic and its influence on the well-being of employees who work in labour-intensive industries. More specifically, the level of stress among these workers is increased and that can result in physical and mental health issues, resulting in low mood and motivation, anxiety, depression, burnout, suicidal thoughts, etc. This may ultimately influence the turnover intention in these industries. Research goal: This paper investigates whether a relationship exists between entrepreneurial organizational culture and turnover intention. The goal of this study is to explore the relationship between entrepreneurial organizational culture and turnover intention in labour-intensive industries with a focus on the mediating role of fear of COVID-19, psychological distress and job satisfaction in turnover intention. Data: Quantitative research on 408 respondents has been conducted, whose results can serve as a reference for designing adequate human resource policies in labourintensive industries. Findings: This study shows that COVID-19 challenged not only economic and financial sustainability, but also the physical and mental well-being of the people. It shows that the organizations that foster an entrepreneurial culture assist people in reducing stress, resulting in members of those organizations experiencing less tension and fear, which is an important part of one's health at such a chaotic time. Contribution: The paper is the first of its kind study and it expands existing research related to organizational culture during the pandemic, thus formulating practical suggestions to future leaders. This study has important implications for practitioners. Although no similar studies exist within the labourintensive businesses, the analysis of these aspects will enable the leaders to assess and strengthen their connections to the company and to determine which segments of their organizational culture need to be improved so that employees should be happier and more satisfied.

Keywords: organizational culture, psychological distress, satisfaction with organizational culture, turnover intention, COVID-19, labour-intensive industry

JEL classification: M1, I1

\section{Introduction}

COVID-19 has brought various changes to every aspect of living, which subsequently contribute to an increased level of anxiety and depression among people. Doubtlessly, the COVID-19 pandemic is the largest public health crisis that the world remembers, one that causes an economic crisis through decreased production in affected countries, fall in confidence and consumption, and a stock exchange negative response. Besides, the pandemic has resulted in questioning the importance of the culture that every organization nurtures. Organizational culture has never been more important than in the COVID-19 period because the 
pandemic forces radical changes in the workplace. Holding teams together, motivating people, taking care of them, and leading informally become as equally important as the concept of leadership.

It is fascinating to see how people, who were not happy with the culture of the organization they were working in before COVID-19 are now worried about the many changes organizational culture has had to go through during the pandemic. In fact, these changes that become a reason for the leaders to rethink the culture will not disappear once the pandemic stabilizes itself. The organizations will continue to cope with exceptional circumstances such as fight for equality, climate change, technological adaptation and many more. Consequently, the organizational members will constantly be asked for new ways of leading and working.

In this direction, COVID-19 raises a question of which organizational culture type is best suitable in circumstances as such. Research conducted by Kokt and Ramarumo (2015) shows that, in normal circumstances, the most dominant type of culture, rational culture, has a slight impact on stress, which means that in those organizations people experience a higher level of stress. Group and development culture have more effect on stress, while hierarchical culture shows to have no significant relationship with stress. The stress level caused by a specific culture has a positive effect on employees' performance and, therefore, one cannot say which cultural type is good or bad for a company.

\section{Literature Review}

\subsection{Organizational culture}

Culture is an important factor that might affect organizational culture (Hofstede, 1997). Therefore, it "enjoys" its momentum among organizational researchers, consultants and corporate executives. Through the concept of organizational culture, the influence of not only written organizational rules, but also of unwritten norms and values on employees is demonstrated (Dyer, 1988; Schein, 2004). Harrison defines organizational culture as a "distinctive constellation of beliefs, values, work styles and relationships that distinguish one organization from another" (Harrison, 1993 cited in Maleka et al. 2015). On the other hand, Schein (1990) described organizational culture through the concept of iceberg, as something composed of artifacts, perspectives, values and assumptions.

In their studies, Cammeron and Quinn (2011) explain that organizational culture considers classification of different organizational core values. However, there is a divided opinion regardless of the organizational effectiveness and organizational culture: some organizations are more effective if they are flexible, while others can be more effective if they focus on stability (Quinn \& Rohrbraugh, 1983). In this direction, a culture framework is designed, based on four cultural dimensions through which the core values are defined: family, adhocracy, market and hierarchy. The organizations have elements of all four culture types, but there is a dominance of only one specific cultural type (Cammeron \& Quinn, 2011).

Due to its intent to see the world in the "right" way, organizational culture is of great importance and should not be taken for granted by organizational members (Wilkins et al.,1983). It is composed of a variety of contracts through which the employee's expectations, performance outcomes, rewards and punishments, and relationships within the organization are studied. According to Wilkins et al. (1983), there are three situations when organizational culture becomes obvious: when there is a change in the employee's role within the organization; when there is a subculture conflict; and when there are important decisions to be made by the top management.

As stated by Wallach (1983), effective organizational culture requires not only strong mission, purpose and strategies, but also compatibility with the employee's needs and organization. Therefore, he considered three cultural dimensions: bureaucratic, innovative and supportive. He explains that organizational culture cannot be split into three parts, but it is rather a combination of the three cultural dimensions with different intensity levels.

Entrepreneurial culture is considered to include the attitude, values, abilities, and individual power or group working together to generate profit. At the heart of entrepreneurial organization, there is innovation, one of the most crucial elements for organizational growth and success (Kang, Matusik, Kim \& Philips, 2016). Entrepreneurial activity is considered to have a significant positive relation with the organizational growth and self-efficacy (Baum \& Locke, 2004). This means that the firms that show a low level of entrepreneurial activity are less profitable, and they grow slowly, in comparison with the organizations whose entrepreneurial activities are on a higher level. 
The mindset of being innovative needs to be driven through all organizational levels. It is not just the top management that need to be entrepreneurially oriented, but all organization members should nurture creativity and stimulate it. The organizations that nurture a truly entrepreneurial culture will gain a strong competitive advantage on the market, because the change rate is increasing in every field and industry (Gadodia, 2020). Thus, the culture that encourages innovativeness and creativeness is of vital importance for organizational success (Pohlmann et al., 2005), where the entrepreneurial leaders are playing a main role in developing and stimulating innovation at work (Shalley \& Gibson, 2004). In this direction, organizational culture is linked with leaders' behaviour. The employees' function in maintaining organizational culture should be appreciated by the leaders, so that healthy work environment should be created. Work recognition and satisfaction can be achieved when the tasks are completed by the employee. Subsequently, organizational culture has a significant role in building a happy and healthy workplace.

\subsection{Psychological distress, job satisfaction and turnover intention in times of COVID-19}

As a consequence of the external environment, stress is characterized as an individual response to what puts pressure on that individual (Ivancevich, Konapske \& Matteson, 2006). It is an actual response to different stressors, among which work-related stress. Having this in mind, work-related stress can be considered as a response from the employee because of the work demands and pressures that do not correlate with their knowledge, abilities and skills. Depending on the stress level, stress can contribute to either positive or negative job performance. Lack of stress can result in decreased performance, due to bounded work challenge. However, if the stress increases, the performance increases as well, as the employee makes an effort to use all the resources that are needed for a specific task to be completed. At this stress level, employees have proven to perform beyond the limits and productivity. Yet, when the stress reaches the saturation point, the performance starts decreasing and the employees show inconsistent behaviour (Fonkeng, 2018).

Consequently, stress has a negative impact on both individual and organizational levels. On an individual level, the person experiences unhealthy symptoms, while what is experienced on the organizational level is a high rate of employee turnover and absenteeism. Additionally, the organization will face various issues such as: reduced efficacy, lack of apprehension, performing capacity, responsibility, input, product or service quality and morale (Dua, 1994; Ben-Baker et al., 1995).

Stress is especially emphasised during global pandemics like SARS, Ebola or COVID-19. It is not only a result of the fear of contracting the virus, but also of the fear of separation from family and friends, uncertainty and feeling of helplessness (Li \& Wang, 2020; Cao et al., 2020). Regarding work-related stress, employees who work remotely from home are exposed to different psychosocial risk, for instance: isolation, no workfamily boundaries, fear of losing the job, decreased salaries, reduced benefits, etc. All these aspects may have impact on people's mental health (Lund et al., 2018).

Due to psychosocial risks, the level of stress among people is increased and that can result in physical and mental health issues. People's response to the issue includes a low mood and motivation, anxiety, depression, burnout, suicidal thoughts (Stansfeld \& Candy, 2006) and health problems. Besides, there can be a change in behaviour such as increased use of alcohol or drugs as a "tool" for coping with the circumstances and trying to relax.

According to Shiu (2020), "job stress is not a new phenomenon in any industrial society and, historically, workload has been a key contributor to workplace anxiety. Yet, COVID-19 has caused other factors to suddenly take the centre stage in influencing people's levels of job stress". There are three key reasons for increased stress in the workplace: income, fear of being exposed to the virus when at work, and fear of losing the job. In addition, stress is present among the work-from-home employees. This is due to the people's inability to separate personal from work life as well as the stress created by simply working from home. Home working can even lead to sleeping or eating disorders, which can further result in psychological stress.

Psychological risks and stress have been considered to have an impact on job satisfaction and other work aspects such as motivation and work engagement. Job satisfaction is the degree to which people like or dislike their jobs (Gimenez-Espert et al., 2020). It is influenced by financial packages, development opportunities, and working conditions (Rue \& Byars, 2003) as well as independence, superior support, personal development and relationships within the organization.

The literature suggests that satisfied employees are associated with greater productivity in comparison with employees who show no satisfaction (Likert, 1961). That does not mean that dissatisfied employees may quit the job, but the feeling of dissatisfaction will be reflected on the employee's performance (Squires et al., 2015). 
Moreover, in a COVID-19 situation, according to the study conducted by Bellmann and Hubler (2020), there is a positive correlation between remote work and job satisfaction. However, there is no statistical significance regarding the preference of working hours and remote work, although working later in the day is considered negative while working early in the day is positive. This is reasonable if one takes into consideration that longer working hours are linked with lower level of job satisfaction. Therefore, organizations should offer their employees opportunities to work remotely and should not restrict longer working hours.

A higher level of stress and a lower level of job satisfaction can lead to increased employee turnover. This concept refers to the ratio of employees who leave an organization, expressed as a percentage of total workforce numbers (CIPD, 2014). Work-related, personal, and external factors are mostly used to explain why employees quit the job (Mayihnan \& Pandey, 2008). It is defined by different organizational conditions: salary, service, performance, job satisfaction, leadership style, promotion opportunities and commitment. As a consequence of a high turnover rate, the company can face challenges related to higher costs, lower performance and productivity, and low competitiveness (Long et al., 2012). People usually quit their job because their expectations are not met; the job is incompatible with their qualifications and skills; there is stress; there is lack of feedback, confidence, and trust; while no opportunities are offered (Branham, 2005).

In this direction, COVID-19 poses a question of the role of organizations in a pandemic, those that nurture entrepreneurial culture, and the role of fear, stress, satisfaction with organizational culture and turnover intention in entrepreneurial organizations.

\section{Methodology}

\subsection{Sample}

This was a quantitative research with a questionnaire as the main method of data collection. Convenience sampling was used. The main inclusion criteria were: labour-intensive industries classified as small and medium enterprises, with entrepreneurial organizational culture (measured through Vox Organizationis). In accordance with this criteria, the research was conducted in 30 small and medium-sized enterprises in the Republic of North Macedonia, on a total sample of 408 participants: 378 employees and 30 leaders. All 30 companies belong to the private business sector. Since this research was part of a larger national investigation of organizational culture, only the companies with entrepreneurial culture were retained for this research.

Overall, there were 408 respondents in the study (49\% females and $51 \%$ males). The age dissemination suggested that the majority of the employees $(41 \%)$ are between $25-35$ years old, followed by the 35-45 years old (30\%) and $45-55(20 \%)$, while the respondents aged $55+$ account for only $9 \%$. The majority had two children. Regarding the marital status, the dominant majority were married $(76 \%)$.

\subsection{Instrument}

The instrument consisted of the following five main sections:

- Demographic data - demographic and job-related data were collected. In line with the main research aim, demographic data included self-reported health related to COVID-19; while job-related data included items on adequate working conditions (opportunities for practising COVID-19 measures at the workplace), access to adequate working equipment and salary level;

- Fear of COVID-19 Scale (FCV-19S) - a seven-item scale, using a five-item Likert-type scale (1= "strongly disagree"; $5=$ "strongly agree"). Higher scores indicate a higher fear of COVID-19 $(\alpha=.77)$ (Ahorsu et al., 2020);

- Vox Organizationis and satisfaction with organizational culture - the instrument is used to assess the type of organizational culture and leadership style. Using this instrument the research also assessed satisfaction with organizational culture. For the purpose of the research, only companies with entrepreneurial culture and leadership style were included. ( $\alpha=.79)$ (Bojadjiev, 2019);

- General Health Questionnaire 12 (GHQ-12) - This is a tool for screening mental disorders (in both community and workplace settings) that covers feelings of strain, depression, inability to cope, anxiety-based insomnia, lack of confidence and esteem, and other symptoms of psychological distress. $(\alpha=.85)$ (Petkovska, Bojadziev \& Stefanovska, 2015);

- Turnover intention - turnover intention was assessed through a one-item survey. Answers were recorded on a 5-point Likert-type scale where 1 meant "strongly disagree" and 5 meant "strongly agree". Higher scores indicated higher turnover intention $(\alpha=.78)$. 


\subsection{Procedure}

Data were collected in the period from June to November 2020. A link to the online survey was sent to all eligible participants. The invitation email contained information on the purpose of the research, as well as on the voluntary and anonymous nature of the survey. A total of 408 eligible participants submitted fully completed surveys.

\subsection{Data analyses}

Descriptive statistics was used to describe the basic features of the sample in the study, with chi-square tests and two-sided t-tests were used to test differences between the samples on significant characteristics. Significant differences in the data were explored through univariate analyses $(p<0.05)$. Data analysis was performed with IBM/SPSS version 22.0 and SmartPLS 2 software.

\section{Results}

The means and standard deviations of fear of COVID-19, job satisfaction, psychological distress and turnover intention were $28.30 \pm 3.15,3.51 \pm 1.21,5.43 \pm 2.34$, and $2.8 \pm 0.68$, respectively. Furthermore, the correlation coefficients between the variables are presented in Table 1. The results indicate that there is a significant positive relationship between psychological distress and fear of COVID-19 $(p<0.05)$. A significant negative relationship was found between turnover intention and fear of COVID-19 $(p<0.05)$, as well as between job satisfaction and fear of COVID-19 $(p<0.01)$, and job satisfaction and turnover intention $(p<0.01)$.

Table 1: Correlation coefficients among fear of COVID-19, psychological distress, turnover intention and job satisfaction

\begin{tabular}{|l|c|c|c|c|}
\hline \multicolumn{1}{|c|}{ Variables } & $\begin{array}{c}\text { Psychological } \\
\text { distress }\end{array}$ & $\begin{array}{c}\text { Fear of } \\
\text { COVID-19 }\end{array}$ & $\begin{array}{c}\text { Turnover } \\
\text { intention }\end{array}$ & $\begin{array}{c}\text { Satisfaction with } \\
\text { organizational } \\
\text { culture }\end{array}$ \\
\hline $\begin{array}{l}\text { Psychological distress } \\
\begin{array}{l}\text { Fear of COVID-19 } \\
\text { Turnover intention }\end{array}\end{array} \begin{array}{l}\text { Satisfaction with organizational } \\
\text { culture }\end{array}^{.535^{\star *}}$ & .142 & $-.219^{*}$ & - & \\
\hline
\end{tabular}

${ }^{*} p<0.05^{* *} ; p<0.01$

The analysis of GHQ-12 results indicated that $29 \%$ of the participants suffered psychological distress. The analysis indicated higher scores among single mothers $(\mathrm{OR}=3.17 ; 95 \% \mathrm{Cl} 1.9-5.9 ; \mathrm{p}<0.001)$ and those who had minor children $(\mathrm{OR}=2.9 ; 95 \% \mathrm{Cl} 1.4-5.5 ; \mathrm{p}<0.001)$. In addition, a negative relationship was found between higher scores in entrepreneurial culture and psychological distress $\left(x^{2}=33.5, p<0.001\right)$, while a positive relationship was identified between turnover intention and fear of COVID-19. This means that respondents who demonstrated a greater fear of COVID-19 were more prone to consider leaving their job.

The results of univariate analysis of the association between organizational-, job- and health-related worker characteristics on one hand, and satisfaction with organizational culture results on the other hand indicated that higher scores in entrepreneurial leadership and culture had a positive association with satisfaction with organizational culture in cultures and with leaders who are more entrepreneurial, thus having employees with higher satisfaction with organizational culture rates $(\mathrm{OR}=1.60,95 \% \mathrm{Cl} 1.02-1.65, p<.01 ; \mathrm{OR}=0.97,95 \%$ $\mathrm{Cl} 0.94-1.03, p<.05)$. Salary level was also found to be significantly associated with satisfaction with organizational culture, with participants who have lower salaries demonstrating lower satisfaction with organizational culture compared to the participants who were in the higher income group $(\mathrm{OR}=0.94,95 \% \mathrm{Cl}$ $0.91-1.02, p<.05)$. Health-related factors, such as having a chronic illness or classifying oneself as belonging to a COVID-19 health risk group were associated with lower levels of satisfaction with organizational culture $(\mathrm{OR}=-1.10,95 \% \mathrm{Cl} 1.03-1.14, p<.05 ; \mathrm{OR}=-1.06,95 \% \mathrm{Cl} 1.01-1.15, p<.05)$. Finally, adequate working conditions and working on adequate equipment were related with higher satisfaction with organizational culture scores $(\mathrm{OR}=1.20,95 \% \mathrm{Cl} 1.03-1.13, p<.05$; $\mathrm{OR}=1.30,95 \% \mathrm{Cl} 1.04-1.21, p<.05)$. 
Table 2: Results of univariate analyses of the association between organizational and personal health characteristics on one hand, and job satisfaction results on the other

\begin{tabular}{|l|c|c|c|c|}
\hline & OR & $\begin{array}{c}\text { Lower } \\
\mathbf{9 5 \%} \mathbf{~ C I}\end{array}$ & $\begin{array}{c}\text { Upper } \\
\mathbf{9 5 \%} \mathbf{~ C I}\end{array}$ & $\mathbf{P}$ \\
\hline Organizational characteristics & & & & \\
\hline Entrepreneurial leader (higher score) & 0.97 & 0.94 & 1.03 & $<05$ \\
\hline Entrepreneurial culture (higher score) & 1.60 & 1.02 & 1.65 & $<01$ \\
\hline Organizational characteristics & & & & \\
\hline Adequate work equipment (yes) & 1.2 & 1.03 & 1.13 & $<05$ \\
\hline Adequate working conditions (yes) & 1.3 & 1.04 & 1.21 & $<05$ \\
\hline Salary (high level) & 0.94 & 0.91 & 1.02 & $<05$ \\
\hline Health issues & & & & \\
\hline Chronic disease (yes) & -1.10 & 1.03 & 1.14 & $<05$ \\
\hline Belong to COVID-19 risk group (yes) & -1.06 & 1.01 & 1.15 & $<05$ \\
\hline Know someone who has died from COVID -19 (yes) & -1.48 & 1.22 & 1.57 & 1.05 \\
\hline
\end{tabular}

Finally, a path analysis was carried out to test the mediating role of fear of COVID-19 and psychological distress on the relationship between entrepreneurial culture and turnover intention. Figure 1 demonstrates the results of the path analysis method that is used here. The values of $\beta$ coefficient for fear of COVID-19 and psychological distress with entrepreneurial culture were $\beta=-0.497$ and $\beta=-0.325$, respectively. Furthermore, the $\beta$ coefficients for fear of COVID-19 and psychological distress with turnover intention were $\beta=0.410$ and $\beta=0.373$, respectively. Finally, the values for the $\beta$ coefficient for entrepreneurial culture and turnover intention were -0.087 . All t-index values were significant.

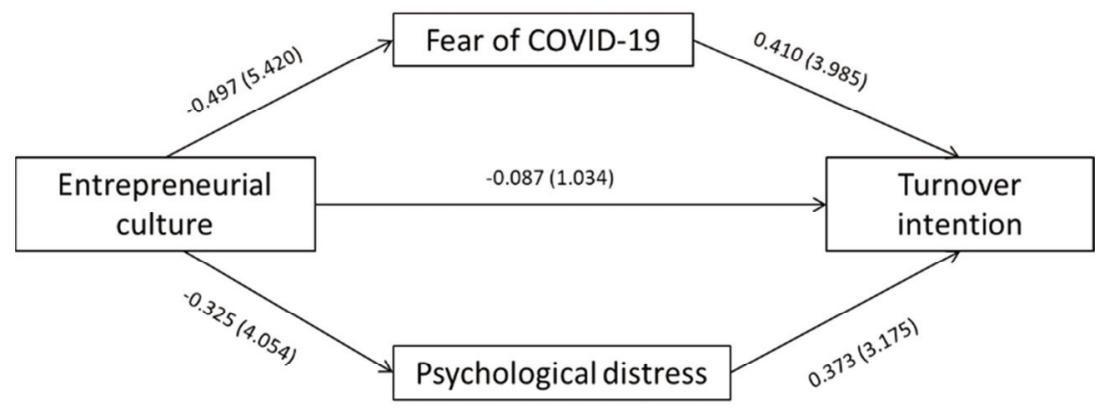

Figure 1. Predicting model for work-life balance based on coping ability, psychological distress and fear of COVID-19 ( $\beta$-coefficients and t-indexes)

Therefore, analyses has indicated that there is a negative and significant relationship between fear of COVID-19 and entrepreneurial culture $(r=-0497, t=5.420)$ and a positive and significant relationship between fear of COVID-19 and turnover intention $(r=0.410, t=3.985)$. Entrepreneurial culture $(r=-0.325, t=4.054)$ and turnover intention $(r=0.373, t=3.175)$ both had a significant relationship with psychological distress. Finally, there was a significant negative relationship between entrepreneurial culture and turnover intention $(r=-0.087, t=1.034)$.

\section{Discussion}

This study investigated the entrepreneurial organizational culture during a pandemic in a labour-intensive industry, through the fear of COVID-19, psychological distress, satisfaction with organizational culture satisfaction and turnover intention. To our knowledge, this study is the first of its kind, thus contributing significant results to the field of organizational behaviour.

Due to the pandemic, the fear of COVID-19 proves to have a significant impact on job satisfaction, psychological distress and turnover intention. People's feelings of fear and anxiety are a result of fear of being infected or infecting others, of social distancing, quarantine, work performance and their emotional and 
psychological well-being. In this study, increased fear of COVID-19 is associated with increased scores on stress level. This means that people who considered themselves as highly fearful of COVID-19 tend to experience a higher level of stress, but a lower level of satisfaction with organizational culture and an intention to quit. The study conducted by Satici et al. (2020), linked the increased level of fear of COVID-19 with negative emotions such as anxiety, stress and depression. Furthermore, another study showed similar idea that the COVID-19-related fear has a significant positive relationship with those negative feelings (Bakiogly et al., 2020). Although fear is considered to be a useful "tool" for motivating individuals to respond effectively, the extreme fear may lead to stress, anxiety or other negative psychological reactions (Gorman, 2008).

COVID-19 does not spare job satisfaction and turnover intention since the fear of it is considered to decrease job satisfaction and turnover intention. As an explanation, previous results provide an understanding that a higher level of negative emotions such as stress, may lead to lower level of satisfaction and performance (McCarthy et al., 2016). Although job satisfaction is considered to have a significant relationship with the turnover intention (Mahdi, 2020), this has not been a case during the COVID-19 pandemic. The explanation behind this is that people do not feel comfortable changing workplaces in highly uncertain circumstances. Furthermore, in the long term, this dissatisfaction may lead to an increased employee turnover rate.

The study shows that in entrepreneurial organizations a higher level of satisfaction among the employees is experienced. This can be ascribed to the higher salary level and the excellent working conditions provided to organization members. Despite that, fewer possibilities of health risks at/in the workplace during the COVID-19 pandemic contribute to the higher level of satisfaction and, at the same time, to lower psychological stress experienced by organization members.

According to the results, the fear of COVID-19 can contribute to employees' increased intention to quit their job. Generally, this can be attributed to the stress and anxiety that organization members experience. However, in organizations that nurture entrepreneurial culture, there is a smaller chance that employees will report a COVID-19 fear and their intention to quit the job is much lower. Moreover, a negative and significant relationship between fear of COVID-19 and entrepreneurial culture is determined. Although the pandemic brings a lot of challenges, entrepreneurial organizations respond to uncertainty by being flexible, adoptive, and supportive to the business environment. Finally, organizations that nurture entrepreneurial culture help people to relieve stress, therefore the members of those organizations experience less stress and fear, which is a crucial aspect of one's health in hectic times as these.

Yet, there are certain inherent limitations to this study. First, the study was conducted in the Republic of North Macedonia, so the reflection from other countries may affect the generalizability of the findings. The second risk is the social desirability bias.

Conclusion, contribution and Practical Implications

The COVID-19 pandemic has significantly changed the workplace landscape with most of the global workforce moving into teleworking. However, this was not an option for the labour-intensive industries as their operations are highly dependent on the physical presence of the employees at the workplace. Hence, the pandemic challenged not just their economic and financial sustainability, but also the physical and mental well-being of their employees. By conducting quantitative research on 408 employees from these industries, the study found a significant association among entrepreneurial culture, fear of COVID-19, stress, job satisfaction and turnover intention. However, the findings should be taken with caution as additional factors may also play an important role in explaining the perception and feelings of the employees. For this reason, it is recommended that future studies explore additional individual and organizational variables that may influence the turnover intention in the light of the COVID-19 pandemic.

In times of uncertainty, such as the COVID-19 pandemic, organizations need to reinvent their organizational culture to encompass the needs of the employees, organization and the wider economic environment. Aspects such as organizational support, training, internet access infrastructure, support in increasing digital literacy, and understanding the individual wellbeing of employees, become an essential part in the survival mechanisms of an organization. The novelty of this study builds on previous studies of organizational culture during the pandemic, resulting in useful recommendations that future leaders may use in times of distress.

In addition, the context in which the study was implemented, allows for raising a set of questions that can be taken into account by future research. More specifically, the pandemic has demonstrated that although the managerial world encountered a myriad of disruptions, these changes in normality presented an excellent opportunity for researchers to bet- 
ter understand organizations. The first set of potential opportunities rest in the assessment of the resilience of organizational cultures in turbulent times. How do they react? Do they transform and in what ways? If organizational cultures change, then what is the impact of these changes on the individuals and organizations? How do they impact the well-being of employees? These are all questions that have existed in the research field for decades, however there was no better time to explore them than now.

Although no similar studies exist in labour-intensive businesses, the analysis of these aspects will allow leaders to assess and strengthen their connections to the company, as well as determine which aspects of their organizational culture need to be improved in order that employees be happier and more satisfied. Contextually, caution should be present in generalising the study findings in organizational systems of other developing countries due to potential situational and cultural differences. The relevance of measuring organizational culture and its link with COVID-19 fear, psychological distress, satisfaction with organizational culture, and turnover intention should be considered by leaders and practitioners in the field alike.

\section{REFERENCES}

[1] Ahorsu, D.K et al. (2020). The Fear of COVID-19 Scale: Development and Initial Validation, International Journal of Mental Health and Addiction. Retrieved from: https://www.nlm.nih.gov/dr2/Fear_of_Covid19_Scale_2020.pdf (Accessed: 2 February 2021). DOI: 10.1007/s11469- 020-00270-8.

[2] Bakioglu, F., Korkmaz, O., \& Ercan, H. (2020). Fear of COVID-19 and positivity: Mediating role of intolerance of uncertainty, depression, anxiety, and stress. International Journal of Mental Health and Addiction. DOI:10.1007/s11469-020-00331-y

[3] Baum, J. R., \& Locke, E. A. (2004). The relationship of entrepreneurial traits, skill, and motivation to subsequent venture growth. Journal of Applied Psychology, 89, 587-598.DOI: 10.1037/00219010.89.4.587

[4] Bellmann, L., \& Hubler, O. (2020). Job Satisfaction and Work-Life Balance: Differences between Homework and Work at the Workplace of the Company. Institute of Labour Economics. IZA DP No. 13504.

[5] Ben-Bakr, K.A., Al -Shammari, I. S., \& Jefri, O.A. (1995). Occupational stress in different organizations: a Saudi Arabian survey. Journal of Managerial Psychology, 10(5), $24-28$. DOI:10.1108/02683949510085956

[6] Bojadjiev, M. I. (2019). 'Development of Instrument for Measurement of the Organizational Alignment - from Vox Organizationis to "Four Organizational Culture Types and Four Leadership Styles"', Universal Journal of Management, 7(5), pp. 186-199. DOI: 10.13189/ujm.2019.070504.

[7] Branham, L. (2005). The 7 hidden reasons employees leave: How to recognize the Subtle signs and act before it's too late, Sound view Executive Book Summaries, 27(6). 1-8 Retrieved from http://www.cognitionnet.com/member/resources/summaries/Personnel_HR/7_Hidden_Reasons_Employees_Leave.pdf.

[8] Cammeron, R.E. \& Quinn, K.S. (2011). Onderzoeken en veranderen van organisatiecultuur. 2nd Edition, Den Haag, Academic Service.

[9] Cao, W., Fang, Z., Hou, G., Han, M., Xu, X., Dong, J., et al. (2020). The psychological impact of the COVID-19 epidemic on college students in China. Psych. Res. 287:112934. DOI: 10.1016/j.psychres.2020.112934.

[10] CIPD - Chartered Institute of Personnel and Development. (2014). Employee turnover and retention 2014 CIPD, London. (Online) Retrieved from: http://www.cipd.co.uk/hr- resources/factsheets/employeeturnover-retention.aspx.

[11] Dua, J.K. (1994). Job Stressors and Their Effects on Physical Health, Emotional Health and Job Satisfaction in a University. Journal of Educational Administration, 32(1), 59-78 DOI: 10.1108/09578239410051853.

[12] Dyer, W. G. (1988). Culture and Continuity in Family Firms. Family Business Review, 1(1), 37-50. DOI:10.1111/j.1741-6248.1988.00037.x.

[13] Gadodia,V. (2020). Entrepreneurial Cultures Create Engines of Growth In Organizations. Retrieved from:https://www.entrepreneur.com/article/361173.

[14] Gimenez-Espert, M., Prado-Gasco, V., \& Soto-Rubio, A. (2020). Psychosocial Risks, Work Engagement, and Job Satisfaction of Nurses during COVID-19 Pandemic. Front. Public Health. DOI: 10.3389/fpubh.2020.566896. 
[15] Gorman, J. M. (Ed.) (2008). Fear and anxiety: The benefits of translational research. American Psychiatric Publishing.

[16] Fonkeng, C. (2018). Effects of job stress on employee performance in enterprise. Master Thesis. Centria University of Applied Science, Business Management.

[17] Hofstede, G. (1997). Cultures and Organizations: Software of the mind, London: McGraw-Hill.

[18] Ivancevich, J. Konapske, R. Matteson, M. (2006). Organizational Behaveior Management, New York: McGraw Hill.

[19] Kang, J. H., Matusik, J. G., Kim, T. Y., \& Phillips, J. M. (2016). Interactive effects of multiple organizational climates on employee innovative behavior in entrepreneurial firms: a cross-level investigation. Journal of Business Venturing, 31(6), 628-642. DOI: 10.1016/j.jbusvent.2016.08.002

[20] Kokt, D., \& Ramarumo, R. (2015). Impact of organizational culture on job stress and burnout in graded accommodation establishments in the Free State province, South Africa. International Journal of Contemporary Hospitality Management, 27, 1198-1213. DOI: 10.1108/IJCHM-03-2014-0100

[21] Li, L. Z., \& Wang, S. (2020). Prevalence and predictors of general psychiatric disorders and loneliness during COVID-19 in the United Kingdom. Psychiatry Research, 291, 0165-1781. DOI: 10.1016/j.psychres.2020.113267.

[22] Likert R. (1961). New patterns of management. New York: McGraw-Hill. doi:10.12691/jbms-5-3-5.

[23] Long R. F., Huebner E. S., Wedell D. H., Hills K. J. (2012). Measuring school-related subjective well-being in adolescents. Am. J. Orthopsychiatry 82 50-60. DOI: 10.1111/j.1939-0025.2011.01130.x

[24] Lund, C., et al., (2018). Social determinants of mental disorders and the Sustainable Development Goals: A systematic review of reviews. The Lancet Psychiatry, 5(4), 357-369. DOI: 10.1016/S22150366(18)30060-9

[25] Mahdi, A.F., Zaid Mohad Zin, M., Mohd Nor, R.M. \& Sakat, A, A. (2012). The Relationship Between Job Satisfaction and Turnover Intention. American Journal of Applied Sciences, 9(9), 1518-1526. DOI: 10.3844/ajassp.2012.1518.1526

[26] Maleka, N., Kambuwa, M., \& Karodia, A. M. (2015). Assessing Organizational Culture Management. Arabian Journal of Business and Management (Nigerian Chapter) 3(3). Retrieved from http://www.arabianjbmr.com/pdfs/NG_VOL_3_3

[27] Mayihnan,D.P., \& Pandey,S.K.(2008). The Ties That Bind: Social Networks, Person-Organization Value Fit, and Turnover Intention. Journal of Public Administration Research and Theory, 18(2).

[28] McCarthy, J. M., Trougakos, J. P., \& Cheng, B. H. (2016). Are anxious workers less productive workers? It depends on the quality of social exchange. Journal of Applied Psychology, 101(2), 279- 291. DOI:10.1037/apl0000044.

[29] Petkovska, M. S., Bojadziev, M. I. \& Stefanovska, V. V. (2015). 'Reliability, Validity and Factor Structure of the 12-Item General Health Questionnaire among General Population.', Open access Macedonian journal of medical sciences. ID Design Press, 3(3), pp. 478-83. DOI: 10.3889/oamjms.2015.075.

[30] Pohlmann, M., Gebhardt, C., \& Etzkowitz, H. (2005). The development of innovation systems and the art of innovation management: strategy, control and the culture of innovation. Technology Analysis and Strategic Management, 17(1), 1-7.

[31] Quinn, R. E., \& Rohrbaugh, J. (1983). A spatial model of effectiveness criteria: Towards a competing values approach to organizational analysis. Management Science, 29, pp. 363-377. DOI:10.1287/mnsc.29.3.363.

[32] Rue, L., \& Byars, L. (2003). Management: Skills \& Application. McGraw-Hill Higher Education.

[33] Satici, B., Gocet-Tekin, E., Deniz, M. E., \& Satici, S. A. (2020). Adaptation of the fear of COVID-19 scale: Its association with psychological distress and life satisfaction in Turkey. International Journal of Mental Health and Addiction. DOI: 10.1007/s11469-020-00294-0.

[34] Shalley, C. E., \& Gibson, L. L. (2004). What leaders need to know: a review of social and contextual factors that can foster or hinder creativity. The Leadership Quarterly, 15(1), 33-53. DOI:10.1016/j.leaqua.2003.12.004

[35] Schein, E.H. (1990). Organizational Culture. American Psychologist, 45 (2), pp.109-119.

[36] Schein, E.H. (2004) Organizational Culture and Leadership. 3rd Edition, Jossey-Bass, San Francisco.

[37] Shiu, E. (2020). The global COVID-19 pandemic has created new causes of job-related stress that have displaced the 'traditional' main reason for workplace anxiety - ever-increasing workloads, according to new research. Retrieved from: https://www.birmingham.ac.uk/news/latest/2020/11/covid-19pandemic-creates-new-causes-of-\%27workplace\%27-stress.aspx.

[38] Squires, J.E., Hoben, M., Linklater, S., Carleton.S, L., Graham, N., \& Estarbooks. N, G. (2015). Job Satisfaction among Care Aides in Residential Long-Term Care: A Systematic Review of Contributing Factors, Both Individual and Organizational. Nursing Research and Practice 2015(6):157924. DOI: $10.1155 / 2015 / 157924$

[39] Stansfeld, S., \& Candy, B. (2006). Psychosocial Work Environment and Mental Health - A Meta-Analytic Review. Scandinavian Journal of Work, Environment \& Health, 32, 443-462.DOI: 10.5271/sjweh.1050 
[40] Wallach, E. (1983). Individuals and Organizations: the Cultural Match. Training and Development Journal, 37(2), 28-36.

[41] Wilkins, A. L. \& Ouchi, W. G. (1983). Efficient cultures: exploring the relationship between culture and organizational performance. Administrative Science Quarterly, 28(3), 468-481.

Received: 2021-03-15

Revision requested: 2021-04-15

Revised: 2021-08-24 (2 times)

Accepted: 2021-10-04

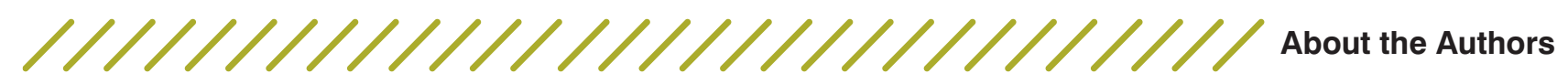

Ivona Mileva, PhD

University American College Skopje, Republic of North Macedonia

ivona.mileva@uacs.edu.mk

Ivona Mileva, MSc, PhDc., is a Teaching Assistant, Chief Academic Officer and Head of Business Administration and Economics Department at the School of Business Economics

and Management, University American College Skopje. She graduated on the topic of

luxury management and, currently, she enrolled in doctoral studies program in a focus of

organizational behaviour field, specifically on the topic of organizational culture. Ivona

Mileva, MSc, has been part of the Leadership Summit Ambassador Program, organized by

People to People at the Harvard University and lately she has been awarded a certificate in

Entrepreneurship from the Harvard Business School. Her academic research is focused on the area of organizational behaviour and management fields with a focus on organizational

culture, leadership and motivation. She has attended a large number of conferences and co-authored academic articles both, domestically and internationally.

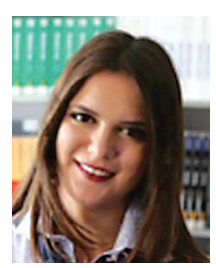

Marjan Bojadjiev, PhD
University American College Skopje, Republic of North Macedonia
provost@uacs.edu.mk

Marjan I. Bojadjiev, PhD is a Provost and a full professor at the University American Collage Skopje since the year 2010. Previously, he has worked as CEO of the Macedonian Savings House from 1996 to 1999 and as CEO of the third largest bank in Macedonia from 1999 to

2004. Prof. Bojadjiev has served as manager of several companies in Macedonia, as a board member in professional organizations and as a moderator in conferences on national Macedonian energy and investment policies. He has completed his doctoral studies at the

Ss. Cyril and Methodius University - Skopje. He earned his Specialization degree in International Business Management at the . He has a Master of Science degree in Banking Marketing. Prof. Bojadjiev has completed executive education courses at in 2008 and 2009.

Miodraga Stefanovska-Petkovska, PhD University American College Skopje, Republic of North Macedonia stefanovska@uacs.edu.mk

Miodraga Stefanovska-Petkovska, MBA, PhD, is an Associate Professor at the School of Political Sciences and Psychology and School of Business Administration and Management, University American College Skopje. She graduated on the topic of individual and economic determinants of retirement and was awarded an honorary Masters degree in business administration on her research on well-being among ageing workforce. She spent part of her doctoral studies at Staffordshire University, United Kingdom as a scholar of the Open Society Institute on the topic of economic trust and cooperation among religious and ethnic minorities. She obtained a doctoral degree in social sciences and gender issues on the topic of discrimination and disparities in health care. Dr. Stefanovska-Petkovska has been awarded a certificate in Statistics for health research from the Oxford University. Her academic research is focused on the area of medical sociology and sociology of health, with special emphasis on the intersection of employment and health, health literacy and selfefficacy. She has co-authored books and academic articles domestically and internationally and has been a mentor/co-mentor of over 20 master theses. She has also been an NGO activist for more than 15 years in the field of HIV/AIDS/STI prevention and management with special focus on vulnerable groups and she has participated, designed and coordinated numerous national and international projects on these issues.
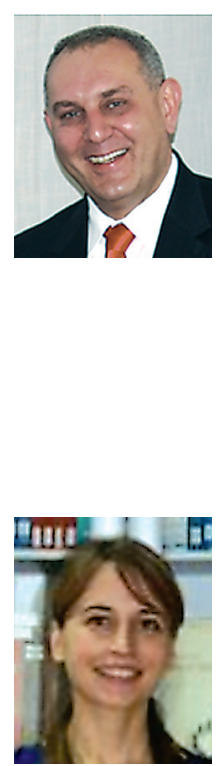